\title{
THE ANNOUNCEMENT: ANNUNCIATIONS AND BEYOND. AN INTRODUCTION
}

We spend our lives waiting for announcements. Time passes monotonously by, then suddenly new information is unveiled, transmitted, often operating as a speech act, as a self-activating enunciation. Announcements are sometimes anticipated, often desired, yet almost by definition unpredictable. The quintessentially post-modern combination of efficiency and ennui has perhaps made us particularly impatient and anxious, constantly checking whether an announcement - a new tax, an invitation to a conference, an amorous email or an immaculate conception - is just around the corner and could change our lives forever.

Each announcement is an event in time: The Annunciation - the announcement to Mary narrated in the Gospel of Saint Luke (Luke 1:26-38) - in particular implies the hardly conceivable simultaneity of the enunciation of the epochal event, its acceptance, and its coming into effect; it posits a curious fragment of time that is no longer the before, but not yet the after; and it creates a complex entanglement between a personal story and general history, with their different temporalities, here suddenly converging. Moreover, there is a particularly significant tension between the Annunciation, as the model and matrix of all announcements, and the long series of reenactments and variations following it. ${ }^{1}$

1 Time is an essential component of any reflection on the Annunciation and there is a substantial body of literature on this aspect. See for instance Daniel Arasse, L'annonciation italienne. Une histoire de perspective, Paris: Hazan, 1999; Lotte Brand Philip, Raum und Zeit in der Verkündigung des Genter Altares, in: Wallraf-Richartz-Jahrbuch 29 (1967), pp.61-104; Louis Marin, Annonciations toscanes, in: Idem, Opacité de la peinture. Essais sur la représentation au Quattrocento, Paris et. al.: Usher, 1989, pp.125-163; Tammy Montgomery, The Angel in Annunciation and Synchronicity. Knowledge and Belief in C.G. Jung: Plymouth et. al.: Lexington, 2013; Carol J. Purtle, Van Eyck's Washington Annunciation: Narrative Time and Metaphoric Tradition, in: The Art Bulletin 81, 1 (1999), pp.117-125; David M. Robb, The Iconography of the Annunciation in the Fourteenth and Fifteenth Centuries, in: The Art Bulletin 18, 4 (1936), pp.480-526; Sarah Stanbury, The Clock in Filippino Lippi's Annunciation Tondo, in: Studies in Iconography 25 (2004), pp. 197-219; Gary F. Waller, A Cultural Study of Mary and the Annunciation: From Luke to the Enlightenment, London: Pickering \& Chatto, 2015. 
Time and history has carried the Annunciation to many different cultures, which have invented their own topoi of announcements. ${ }^{2}$ For instance in contemporary Israel, in the very place of the Annunciation, two thousand years later, the most fundamental and psychologically pregnant topos of this kind would probably be the announcement to a mother and a father of the death of their son in battle. In fact, David Grossman titled his novel about a mother fearing such an announcement $A$ woman fleeing an Annunciation, the last word being the one commonly used in Hebrew for the Marian event. ${ }^{3}$

As this example demonstrates, announcements in general and Annunciations in particular are a persistent phenomenon and an incessant challenge to literature, music - one could recall Paul Hindemith's scoring of Rilke's Annunciation to Mary out of the poem cycle Marienleben (The Life of Mary) ${ }^{4}$ as well as to the visual arts with its ubiquitous iconography. It is thus unsurprising that the theological and philosophical polysemy of the Annunciation touches upon many issues that are still topical today: the question of the Word, of its transformation into concrete material fact; the relation between the announcer - the long-standing figure of the messenger - and the recipient of the message, their inevitable epistemological difference here complicated by their ontological alterity, not to mention the aspect of gender; and the various degrees of expectation and readiness that condition the reception of the message and its subsequent comprehension.

Of course, in this introduction we cannot give an exhaustive account of this subject. ${ }^{5}$ Instead, it will become tangible in the following pages of the book, with themes ranging from duplications of the Annunciation in Byzantine art, to the importance of messengers, from third parties witnessing the miraculous event, to questions of how spaces and places not only frame, but truly create the visible setting for the invisible. We also analyse how the classical theme of the Annunciation can be reused in secular figurative contexts, and how it was appropriated, dissolved and subverted in the Arts of the $20^{\text {th }}$ and $21^{\text {th }}$ centuries.

2 On this topic see Annonces, the film by Nurith Aviv, pp. 219-233 in this volume.

3 David Grossman, Isha Borahat MiBesora, 2008, translated as To the End of the Land, trans. by Jessica Cohen, New York, NY: Knopf, 2010.

4 For a comprehensive analysis of Paul Hindemith's song cycle (1923, revised version 1948) and homage to Rilke, see Michael J. Meyer, 'Dann sang er': Das Marienleben from Rilke to Hindemith, in: Idem (ed.), Literature and Musical Adaptation, Amsterdam/New York, NY: Rodopi, 2002, pp.81103. Furthermore, the brilliant essay by Glenn Gould, A Tale of Two Marienlebens. Liner Notes to 'Das Marienleben', by Paul Hindemith (1992), in: Glenn Gould, Tim Page (eds.), The Glenn Gould Reader, New York, NY: Knopf, 1984, pp.151-163.

5 The bibliography at the end of this book offers an exhaustive overview of this subject. However, at this point we would at least like to mention some of the most fundamental publications: Arasse 1999 (as in note 1); Michael Baxandall, Painting and Experience in Fifteenth-Century Italy, Oxford: Oxford University Press, 1972; Georges Didi-Huberman, Fra Angelico: dissemblance et figuration, Paris: Flammarion, 1990; Ernst H. Gombrich, Norm \& Form. Studies in the Art of the Renaissance, London/New York, NY: Phaidon, 1985; Marin 1988 (as in note 1); Erwin Panofsky, Perspective as Symbolic Form, ed. and trans. by Christopher S. Wood, New York, NY: Zone Books, 1991. 
1 René Magritte, The Annunciation (oil on canvas), 1930, London, Tate Modern Gallery

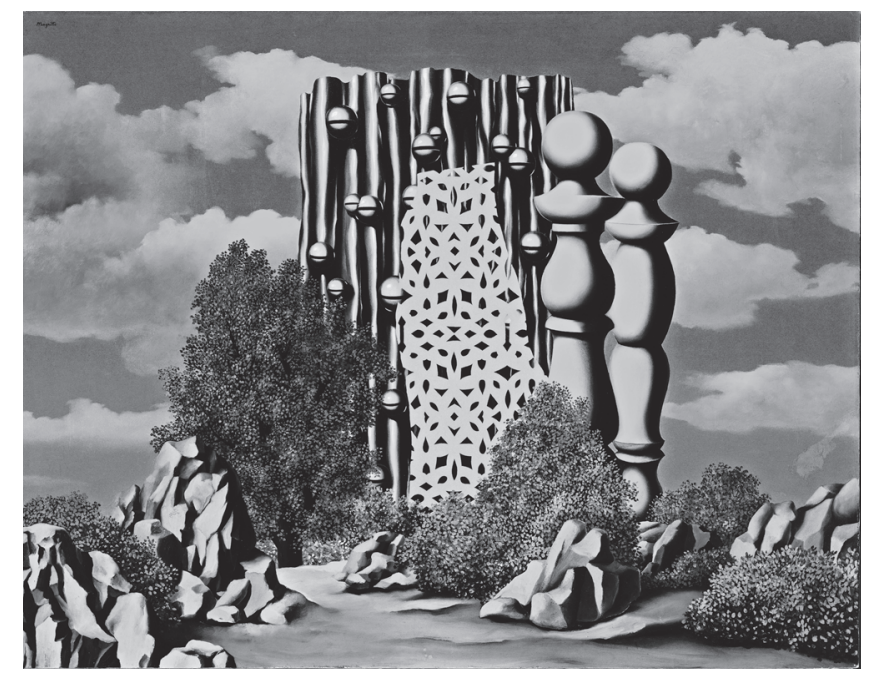

One might think of L'Annonciation (The Annunciation) by René Magritte, which undermines most iconographical and spatial categories, and transforms this culturally familiar motif (often displayed in a domestic environment) into an uncanny and sublime visual experience (fig. 1). ${ }^{6}$ The title is conventional, but is the event even there? Are these alien geometrical forms, which tower above a rocky landscape, the announcement of some cataclysm to come, or could the title just as well be Ceci n'est pas une Annonciation? Certainly, the composition invites us to reflect on what is visible and invisible, representable and irrepresentable, ${ }^{7}$ while also subtly playing with the dialectics of silence and sound so fundamental to any annunciation. ${ }^{8}$ Indeed, even if at first glance the grey rocks

6 For a convincing analysis of Magritte's L'Annonciation see especially David Sylvester, Magritte. The Silence of the World, New York, NY: Abrams, 1992, pp. 185-189. He writes: "There are numerous instances of the sublime in Magritte's art, but nothing else as numinous as this [...] 'The Annunciation' impresses through its majesty, its solemnity, its luminosity, its silence" (Sylvester 1992, p. 187), while also stressing that the grey rocks refer to certain landscapes in Early modern paintings such as, for instance, Domenico Veneziano's St. John in the Desert. One of the most all-encompassing discussions of the work with a broad literary survey can be found here: https://www.tate. org.uk/art/artworks/magritte-the-annunciation-t04367 (accessed January 23, 2020).

7 "Everything we see hides something else; we always want to see what is hidden by the thing we see. It is interesting to know what is hidden and what the visible does not show us. This interest can take the form of a quite intense feeling, a sort of battle, I would say, between the hidden visible and the apparent visible", Magritte quoted in Louis Scutenaire, Jean Clair, David Sylvester (eds.), Rétrospective Magritte, exh. cat. Brussels 1978, Brussels: Palais des Beaux-Arts, 1978, p. 47.

8 Unlike Sylvester, who insists on the silence in Magritte's Annunciation, we would like to stress the implicit acoustic dimension of the painting; see Sylvester 1992 (as in note 6), p.187. 


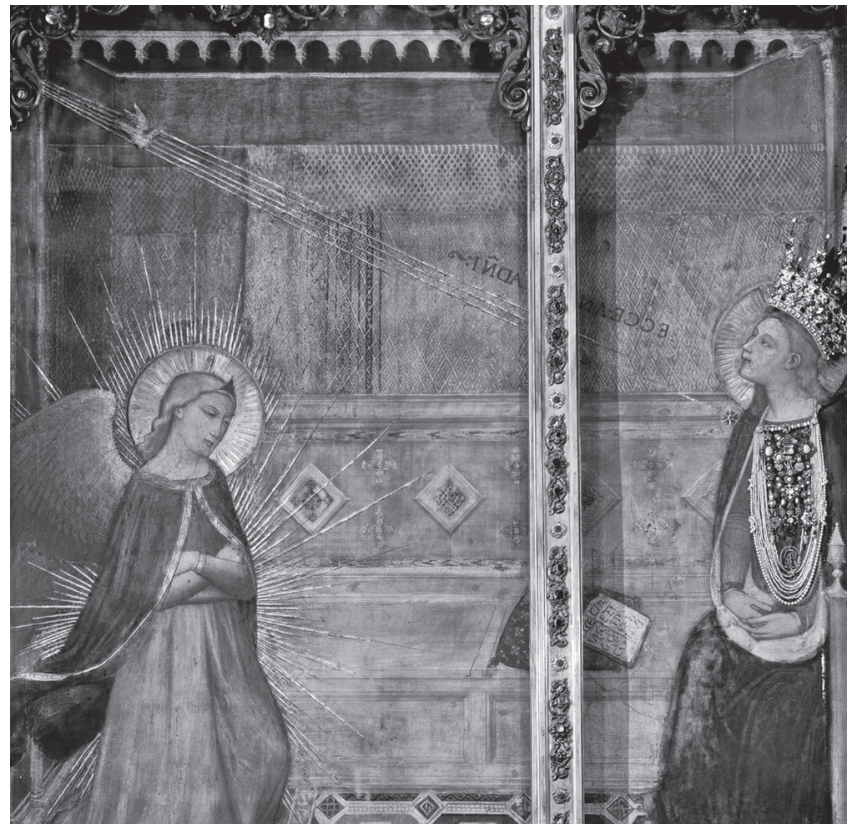

2 Annunciation (fresco), c. 1365 , Florence, SS.

Annunziata (Cappella della SS. Annunziata)

create a static, timeless and silent atmosphere, there is an acoustic and thus temporal quality to the painting: both the trees with their deep green, almost rustling leaves as well as the bell-like forms on the metal curtain evoke a sound, and thus an announcement to come. ${ }^{9}$

\section{Boundaries \& Bodies}

But since this book originated in an international conference in Florence, let us leave aside the meta-theoretical implications of Magritte's provocative Annunciation for a while, and briefly turn our attention to announcements and annunciations in that city. ${ }^{10}$ As Louis Marin and Daniel Arasse have taught us, Florence is the haut-lieu of the theme and the Santissima Annunziata, with the famous miraculous image, is its core and temple (fig. 2). Besides the particular importance the Nunziata, and the legend of its miraculous creation by angels, had for the Serviti, the entire city was under the protec-

9 As we shall see at the end of this introduction, from Origen Adamantius onward, the bell was understood as the acoustic symbol of the announcement of the Christian message.

10 A happy coincidence was the publication, just after the conference took place, of a special issue of the journal Studiolo dedicated to the Annunciation: Studiolo. Revue d'histoire de l'art de l'Académie de France à Rome - Villa Médicis 10 (2013), dossier "L'Annonciation. Hommage à Daniel Arasse". We would like to thank Annick Lemoine, Editor-in-chief of the journal, for her collaboration. 
3 Annunciation (fresco), c. 1365, Florence, SS. Annunziata (view of the Cappella della SS. Annunziata from the nave)

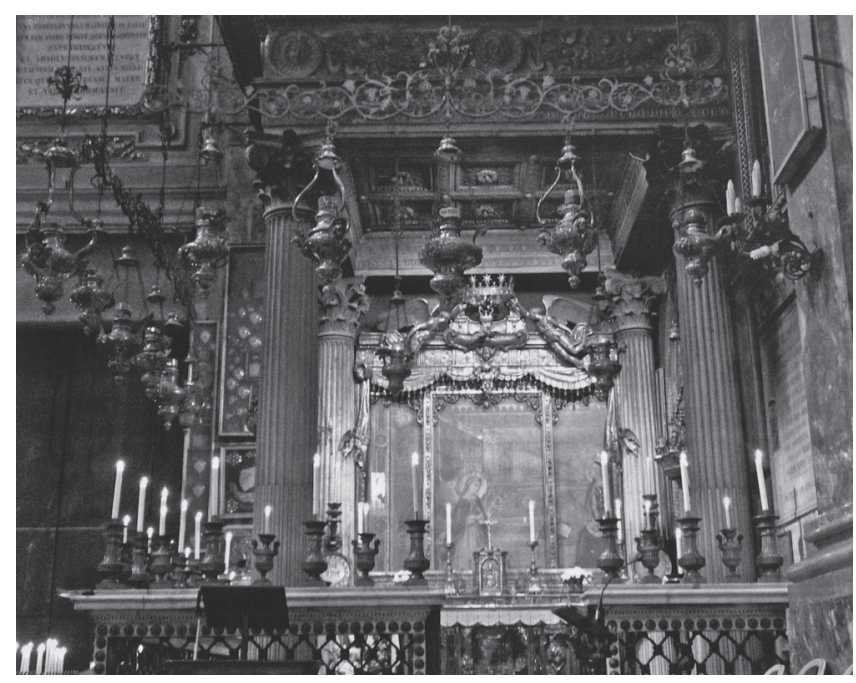

tion of the Madre delle Grazie. ${ }^{11}$ Already in the early Quattrocento the Chapel with the Annunziata fresco had become an integral component of the religious and communal ceremonial of the city (fig. 3). The Medici instrumentalized the image of the Nunziata di Firenze, elevated it to a state icon in the $16^{\text {th }}$ century and promoted its cult far beyond the boundaries of their own territory - as a matter of fact, it attracted pilgrims from many regions - and explicitly emphasized the close connection between the power of the miraculous image and their own political success. ${ }^{12}$

11 Marin 1989 (as in note 1), pp. 159-205; Arasse 1999 (as in note 1), pp. 107-117.

12 There is a substantial body of literature on the SS. Annunziata. See Arasse 1999 (as in note 1), pp.107-117; Eugenio Casalini, La Santissima Annunziata nella storia della civiltà fiorentina, in: Idem, Maria Grazia Ciardi Duprè Dal Poggetto (eds.), Tesori dell'arte della Annunziata di Firenze, Florence: Alinari, 1987, pp.75-79; Elena Giannarelli, Maria, 1'Annunziata nella storia e nella tradizione Fiorentina, in: Timothy Verdon (ed.), Santissima Annunziata, Florence: Centro Di, 2005, pp. 55-75; Sara F. Matthews Grieco, Media, Memory and the 'Miracoli della SS. Annunziata', in: Word E' Image 25, 3 (2009), pp. 272-292; Sabine Hoffmann, Ein Heiliger und sieben Gründer. Der Freskenzyklus zu den Ursprüngen des Servitenordens im Chiostro dei Morti der Santissima Annunziata in Florenz (1604-1618), Berlin: Deutscher Kunstverlag, 2013 (Ph.D. University Münster 2008), esp.chapter 1: "Die Servi di Maria in Florenz. Ihre Heiligen und ihre Bilder", pp.15-76; Megan Holmes, The Elusive Origins of the Cult of the Annunziata in Florence, in: Erik Thunø, Gerhard Wolf (eds.), The Miraculous Image. In the Late Middle Ages and Renaissance, Rome: L'Erma di Bretschneider, 2004, pp.97-121; Stefanie Renner, Die Darstellung der Verkündigung an Maria in der florentinischen Malerei: von Andrea Orcagna (1346) bis Lorenzo Monaco (1425), Bonn: Lemmens, 1996, pp.92-111; Zygmunt Waźbiński, L’Annunciazione della Vergine nella chiesa della SS. Annunziata a Firenze. Un contributo al moderno culto dei quadri, in: Andrew Morrogh, Fiorella Superbi Gioffredi (eds.), Renaissance Studies in Honor of Craig Hugh Smyth, vol. 2, Florence: Villa I Tatti, 1985, pp.533-552; Gerhard Wolf, Miraculous Images between Art and Devotion in Medieval and Early Modern Europe, in: Akira Akiyama, Kana Tomizawa (Kitazawa) (eds.), Miraculous Images in Chris- 
Another nodal point of this Florentine narrative is the convent of San Marco, to which Georges Didi-Huberman dedicated some particularly memorable philosophical observations focusing on the question of non-savoir. ${ }^{13}$ In wandering through the city of the Fiore one could find many staggering annunciations in other churches, but also outside, on façades or street corners.

What should have become clear by now is how the Annunciation (as a motif and a dispositif) is intricately bound up with a whole range of artistic, theological, philosophical as well as political reflections on and problematizations of time and space; and this is why in any representation of this Marian event - whether in $15^{\text {th }}$-century Florence or in $20^{\text {th }}$-century Belgium - the inextricable connection between interior-exterior, incommensurable-measurable and transcendence-immanence is explored and visualised. ${ }^{14}$ As Gerhard Wolf has concisely written, at the core of the problem seems to be the question of how images (and we would add architectural settings) constitute a privileged site for the exchange between the divine and human spheres. ${ }^{15}$ One could say that in the miracle of the Annunciation the attentive recipient is confronted with a complex, yet subtle phenomenology of the threshold, both in its concrete as well as in its metaphorical meaning. And indeed, the role of passages, boundaries and painted architecture in the Annunciation necessitates further analysis that goes far beyond questions of its purely symbolic function. ${ }^{16}$ A particularly spectacular example for such a "phenomenology of the threshold" is the famous Mérode Triptych by Robert Campin, with its wide and impressive repertoire of doors, windows, locks, keys, inner spaces and open places (fig. 4). Here, the Flemish master brilliantly plays with the many semantic levels of intimate and religious, as well as urban and social space and place. ${ }^{17}$

tian and Buddhist Culture. 'Death and Life' and Visual Culture II, Tokyo et. al.: The University of Tokyo, 2010, pp. 99-115.

13 Didi-Huberman 1990 (as in note 5). English translation: Fra Angelico. Dissemblance and Figuration, trans. by Jane Marie Todd, Chicago/London: The University of Chicago Press, 1995.

14 For a reflection on the complex relationship between exterior and interior and the performative staging of the Annunciation see the article by Rimmele in this volume, pp. 89-112.

15 Gerhard Wolf, Schleier und Spiegel. Traditionen des Christusbildes und die Bildkonzepte der Renaissance, Munich: Fink, 2002, esp.p. 212. For a concise discussion of the role of miraculous images in religious contexts, cf. Wolf 2010 (as in note 12).

16 For an analysis of the spatial dimensions of the Annunciation see for instance Michael Camille, The Image on the Edge. The Margins of Medieval Art, London: Reaktion Books, 1992; Didi-Huberman 1995 (as in note 13); Wolfgang Kemp, Die Räume der Maler. Zur Bilderzählung seit Giotto, Munich: Beck, 1996; Julia Liebrich, Die Verkündigung an Maria. Die Ikonographie der italienischen Darstellungen von den Anfängen bis 1500, Cologne et. al.: Böhlau, 1997; Sven Lüken, Die Verkündigung an Maria im 15. und frühen 16. Jahrhundert, Göttingen: Vandenhoeck \& Ruprecht, 2000; Erwin Panofsky, Early Netherlandish Painting: Its Origins and Character, vol. 1, Cambridge, MA: Harvard University Press, 1953; John Richard Spencer, Spatial Imagery of the Annunciation in Fifteenth Century Florence, in: The Art Bulletin 37, 4 (1955), pp. 273-280.

17 A classic study of the altarpiece is Meyer Shapiro, 'Muscipula Diaboli'. The Symbolism of the Mérode Altarpiece, in: The Art Bulletin 27, 3 (1945), pp.182-187. 


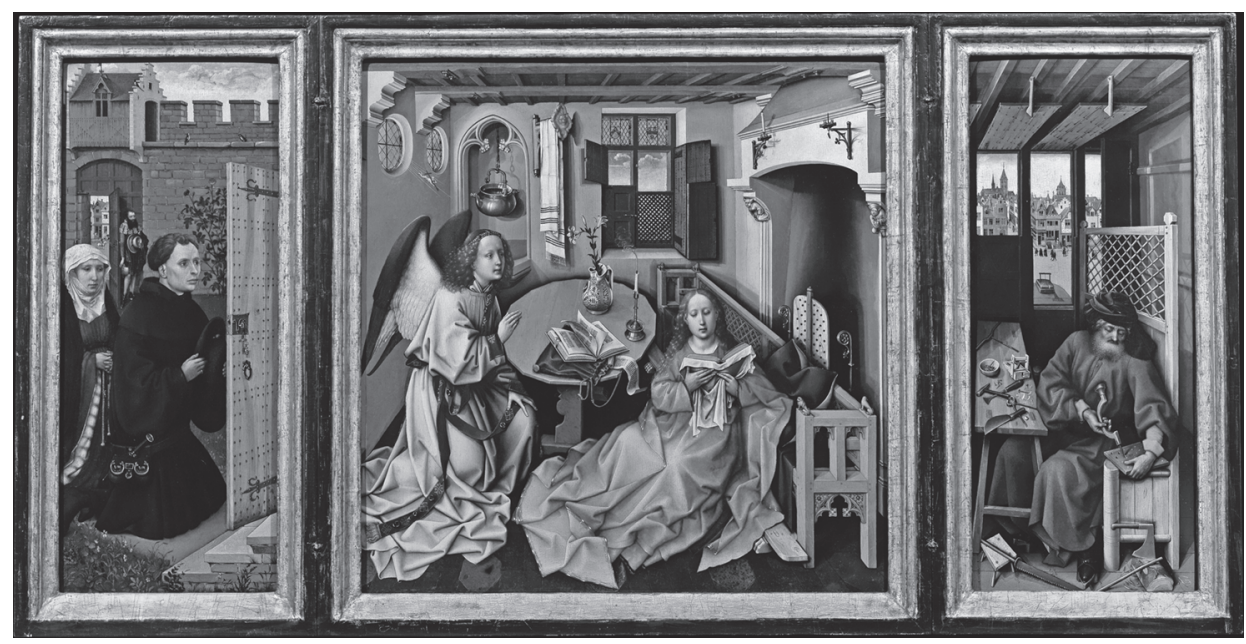

4 Robert Campin, Mérode Triptych (oil on panel), c. 1427-1432, New York, Metropolitan Museum of Art, The Cloisters Collection

However, the inner pictorial space can hardly be understood without its framing, display and relation to the real space in churches and chapels, and the effective position of the beholder. Because the issue of nearness and distance to the miracle of the Annunciation - both in a spatial as well as in an emotional and epistemological sense - is not only connected to the ideal, mental eye - and in this sense not only to linear perspective stricto sensu ${ }^{18}$ - but it strongly involves the body of the devout spectator. ${ }^{19}$ In order to arrive at a holistic comprehension of the Annunciation a refined orchestration of aesthetic and liturgical mise-en-scène, memory, imagination and bodily experience is required. ${ }^{20}$

18 Panofsky 1953 (as in note 16).

19 What is interesting for our purpose here, is that in his final essay Eye and Mind the French philosopher Maurice Merleau-Ponty formulates a critique of central perspective, underlining that one of the major problems is that in the concept of Alberti's Finestra aperta the viewer is not in, but in front of the world. It is a form of bodyless objectifying seeing and thinking that cannot be aware of the richness and complexity of the existential and phenomenal world. In this sense, for Merleau-Ponty perspective becomes the symbol of the construction of a completely dominated world that is not a shared and lived one. The French philosopher stresses that this form of seeing should indeed be complemented by a human, deeply sensuous and bodily seeing. And it is the artist who, according to Merleau-Ponty, by "lending his body to the world [...] changes the world into paintings"; cf. Maurice Merleau-Ponty, Eye and Mind (1961), in: Thomas Baldwin (ed.), Maurice Merleau-Ponty: Basic Writings, London/New York, NY: Routledge, 2004, pp. 290-324, esp.p. 294.

20 For a masterful analysis of the relation between sacred images and holy places see Hans Belting, Image, Medium and Body. Reflections on the Experience of Privileged Spaces, in: Aleksej Michajlovic Lidov (ed.), Ierotopija: issledovanie sakral'nych prostranstv, Moscow: Radunica, 2004, p. 34; Hans Belting, An Anthropology of Images, Princeton: Princeton University Press, 2011, esp. chapter 2: "The locus of Images: The Living Body", pp. 37-61. 


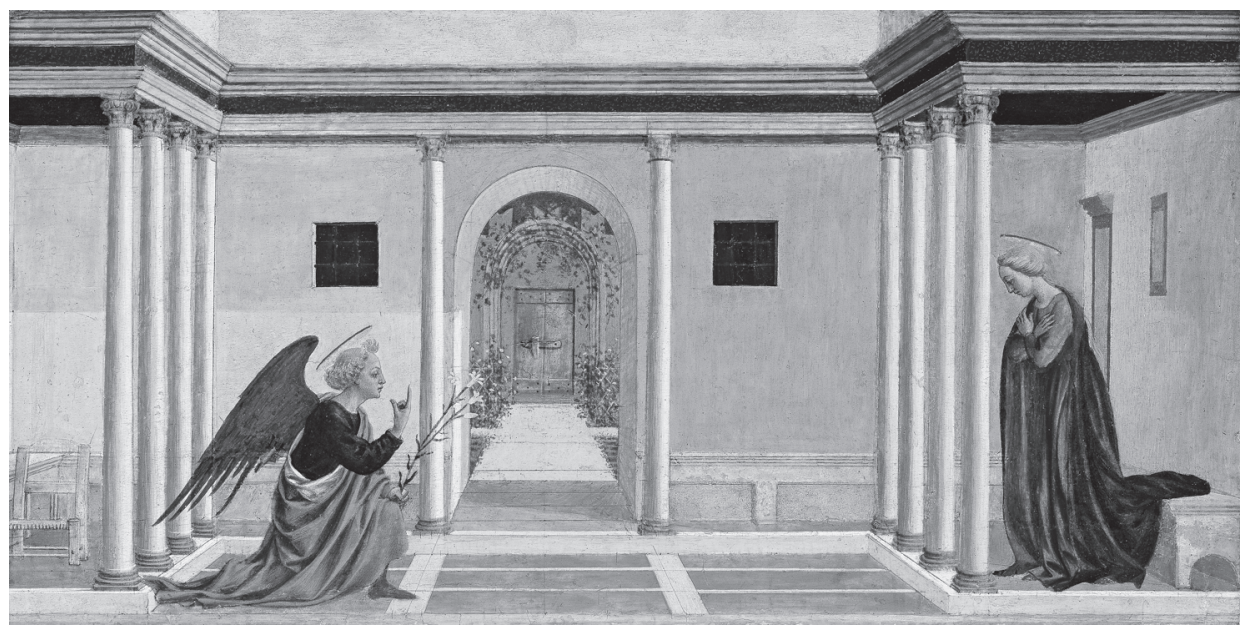

5 Domenico Veneziano, Annunciation (tempera on panel), 1442-1448, Cambridge, Fitzwilliam Museum

As Hans Belting convincingly argues, bodies "are more than merely passive recipients of the visual media that shaped them. Their activity is needed in order to practice visual media in the first place." 21 Therefore, borders, curtains, frames and framings in the broadest sense - and here we can think of the miraculous fresco of the Annunziata enshrined by the baldachin -, as well as the possibility of moving through the concrete architectonical and urban space, play an important role for a polyperspectival visual and bodily experience that emphasizes the intricate relationship of access and inaccessibility, real and imagined spaces and let us become aware of alterity on many levels. The miraculous event of the Annunciation, so often depicted in a domestic environment, and thus in an ordinary and familiar place, always transcends spatial categories and merges utopia and heterotopia - it is fundamentally unreal and sacred (fig. 5). ${ }^{22}$

\section{Visibility \& Crisis}

From Magritte to Campin, we have just unwittingly sketched a Netherlandish genealogy of the Annunciation, perhaps a possible alternative to the theme's evolution in Italy, of

21 Cf. Hans Belting, Image, Medium, Body. A New Approach to Iconology, in: Critical Inquiry 31, 2 (2005), pp.302-319, esp.p. 311.

22 According to Foucault, heterotopias are radically different from the places we live, they are "outside of all places, even though it may be possible to indicate their location in reality." Heterotopias are privileged or sacred or forbidden spaces. Michel Foucault, Of Other Spaces: Utopias and Heterotopias, in: Diacritics 16, 1 (Spring, 1986), pp. 22-27, esp.p. 24. 
which, as is well known, comprehensive accounts abound..$^{23}$ Daniel Arasse's L'Annonciation italienne probably remains the most complete treatment of this pictorial evolution in the Renaissance and of the parallel conceptualization and practice of linear perspective. For Arasse, the costruzione legittima - with its rules and its rigour, but also with some hardly perceptible paradoxes and subtle incoherencies - was for at least two hundred years the favourite tool for the expression and the mise-en-scène of the mystery of the Annunciation, of its miraculous insertion of Eternity in time, of the incommensurable in measure, of the infinite in the finite and of the non-figurable in figure.

In some cases, during those eventful two centuries, the geometrically intricate dispositif was made to simultaneously serve more than one announcement: of Carlo Crivelli's Annunciation with St. Emidius, Stephen J. Campbell writes, "the Virgin's Annunciation prefigures the joyous announcement of civic liberty on Annunciation Day of 1482", when "the city of Ascoli Piceno learned of its liberation on the very day sacred to the announcement of the Incarnation to the Virgin Mary". ${ }^{24}$ The Annunciation thus becomes the spatial and temporal archetype for any important announcement; indeed, in that painting there is even a third event in which news is transmitted: we see on the bridge at the background an official reading a letter that was just delivered to him - perhaps, speculates Campbell, by a carrier pigeon, the mundane replica of the dove of the Holy Ghost. Two centuries later, the ever-resourceful Diego Velázquez liberated the structure from the message and created, in his Apollo in the Forge of Vulcan, a wholly secular Annunciation: the dazzling being descending from the heavens is not Gabriel, those interrupted are not a young, pious Jewish virgin, and the message is a painful story of adultery and treason rather than a divine promise of redemption. Yet, Vulcan and his co-workers exemplify the whole range of reactions traditionally imputed to the Virgin in her case, as a temporal sequence that is paradoxically immediate -, and the narrative model relies quite directly on the long tradition of Marian Annunciations. ${ }^{25}$

Arasse's narrative, instead, is deliberately limited in scope: not only does he stay south of the Alps, but he also traces only three centuries of the story, without taking into account the secular transformation of the motif. At the end of his trajectory, if we leave aside the relatively autonomous Venetian chapter, Arasse reaches Caravaggio, to whom he dedicates a few sentences, and then dramatically declares: "la Renaissance est terminée", "the Renaissance has ended" - and with it the book. ${ }^{26}$

23 See note 1,5 and 16.

24 Stephen J. Campbell (ed.), Ornament $\mathcal{E}$ Illusion. Carlo Crivelli of Venice, exh. cat. Boston 2015-2016, London: Paul Holberton Publishing, 2015, pp. 196-201.

25 For Velazquez's painting see Giles Knox, Velázquez and Inversion: Making and Illusion, in: Idem, Sense Knowledge and the Challenge of Italian Renaissance Art. El Greco, Velázquez, Rembrandt, Amsterdam: Amsterdam University Press, 2019, pp. 87-120; Lee Ashley Pentecost, Ancient Sources for Velázquez's 'The Forge of Vulcan'. Plutarch and Homer, with some Observations on Solar Iconography, in: Bruckmanns Pantheon 44 (1986), pp.50-52.

26 Arasse 1999 (as in note 1), p. 294. 


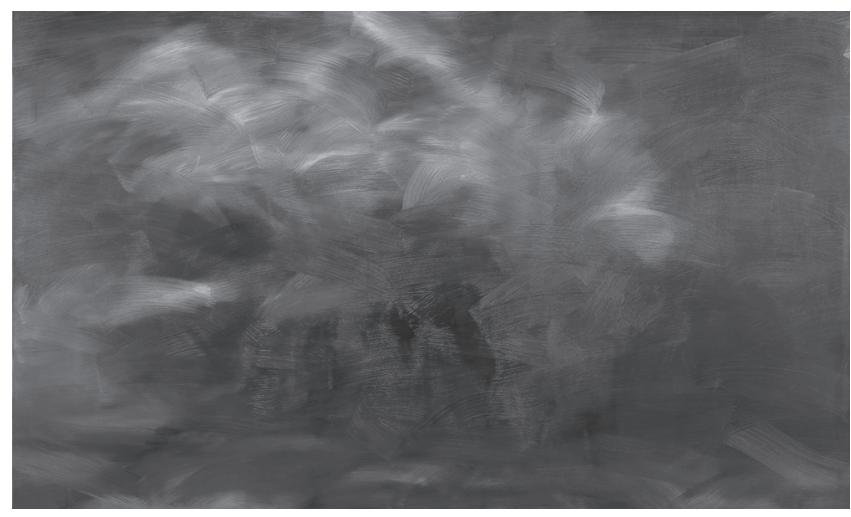

6 Gerhard Richter, Annunciation after Titian (oil on canvas), 1973, CR 344-2, Basel, Kunstmuseum Basel

If, as Arasse masterfully shows, the Annunciation was subject to the most systematic treatment that the Renaissance had to offer, Caravaggio's general annihilation of the Renaissance pictorial system is indeed perfectly exemplified in the artist's only depiction of our trope. In the painting now in Nancy there is of course no perspective and no representation of space at all, as these are drowned by Caravaggio's typical darkness and in the equally informe cloud ( $\mathrm{pl}$. I). But the interpersonal communication - be it verbal or gestural - that could have rendered spatial specificity unnecessary is also absent: the two protagonists relinquish visual interaction altogether, between them, with the objects surrounding them and with the beholder. The angel's Annunciation - like other caravaggesque announcements, such as the Contarelli Calling of Saint Matthew - thus loses its syntactic clarity, and becomes a purely physical effect of presence, literally imposed on the Virgin from above and encompassing her. If knowledge is logos, information, none of it is transmitted here; but for Caravaggio, knowledge is corporeal experience, just as it was for his quasi-contemporary Montaigne. ${ }^{27}$ The Annunciation is now a mystic vision, anticipating a century of baroque art and, indeed, closing the chapter on humanistic annunciations that Arasse brilliantly narrated.

The broader story, however, did obviously not begin in trecento Tuscany - a few earlier examples are discussed in this volume - and it continues long after Caravaggio. The dissolution of perspective, a striking feature in 1600, remained a fertile ground for pictorial experimentation and theoretical reflection even much later. In 1972 Gerhard Richter exhibited his 48 Portraits at the Venice Biennale. It was during his preparatory stay that he saw Titian's San Rocco Annunciation for the first time (pl. II). After taking some photographs, Richter bought a postcard, and being moved by the desire to paint "in the

27 Cf. Itay Sapir, Ténèbres sans leçons. Esthétique et épistémologie de la peinture ténébriste romaine 1595-1610, Bern: Peter Lang, 2012, pp. 129-186. 
7 Gerhard Richter, Annunciation after Titian (oil on canvas), 1973, CR 344-3, Basel, Kunstmuseum Basel

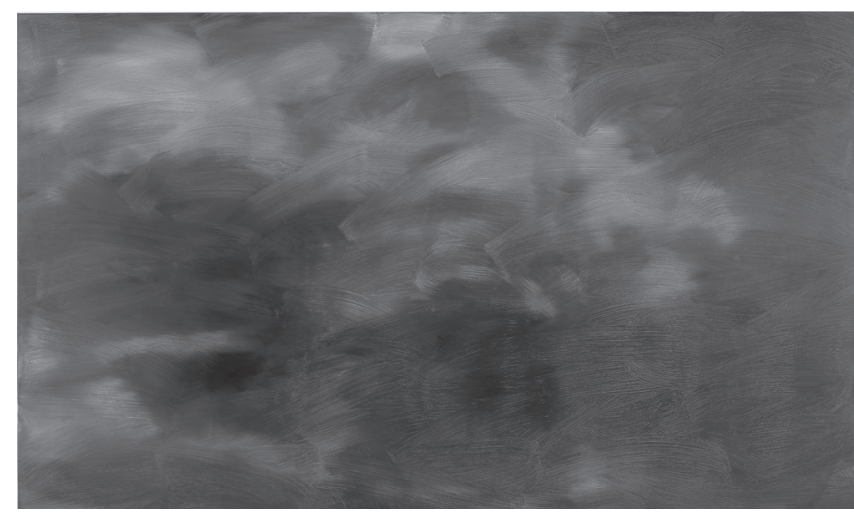

manner of", in 1973 he created a series of five canvases after Titian's work, which he entitled Verkündigung nach Tizian (Annunciation after Titian) (pl. III, fig. 6, 7). ${ }^{28}$ Titian's San Rocco Annunciation is characterized by the relationship between light and darkness, $d y$ namis and stasis, and by a deep interest in the different qualities of reflecting, absorbing and shimmering surfaces. ${ }^{29}$ Richter, for his part, focuses on light and colour, while dissolving perspective. His appropriation of the titianesque Annunciation - significantly Richter's only work with Christian iconography - happened at a transitory moment in his artistic oeuvre, and alludes to topics that are fundamental for his own painterly experimentation and theoretical observation. ${ }^{30}$ The question of seeing, and of coming into being, comes to mind, but also the transition from the Abbild to the Farbbild, from rep-

28 In an interview, Richter explained: "When I saw Titian's painting in the Accademia I just wanted it for myself, for my apartment, so I decided to copy it as far as I could. But I couldn't even manage a semi-presentable copy. So then I painted five variations on the Annunciation that didn't have much to do with Titian's Annunciation but that I was quite happy with." Gerhard Richter, Text. Writings, Interviews and Letters/1961-2007, ed. by Hans Ulrich Obrist and Dietmar Elger, London: Thames \& Hudson, 2009, p. 511 (Interview with Jeanne Anne Nugent, 2006). For Richter's Annunciation see especially the following books and articles: Gavin Hopps, Being in Uncertainties, in: Christianity $\mathcal{E}$ Literature 67, 3 (2018), pp. 559-567; Sven-Olov Wallenstein, The Annunciation of the Sensible. Gerhard Richter's 'Verkündigung nach Tizian', in: GdM 2 (2015), pp.322-335; Michael Wetzel, Die Wahrheit nach der Malerei, Munich: Fink, 1997, pp. 209-210. See also Helmut Friedel (ed.), Rot Gelb - Blau. Die Gemälde für BMW, Munich: Prestel, 2007, pp.17-18; Julia Gelshorn, Aneignung und Wiederholung. Bilddiskurse im Werk von Gerhard Richter und Sigmar Polke, Munich: Fink, 2012; Erik Verhagen, Rendre l'inexplicable accessible. Les Annonciations d'après Titien de Gerhard Richter (1973), in: Studiolo 10 (2013) (as in note 10), pp. 166-174, 323-324.

29 For Titian's Annunciation of San Rocco see Arasse 1999 (as in note 1), pp.311-320. For Titian's highly complex exploration of the Annunciation, and the problem of incarnation and its relation to art theory see Daniela Bohde, Haut, Fleisch und Farbe. Körperlichkeit und Materialität in den Gemälden Tizians, Emsdetten et. al.: Edition Imorde, 2002.

30 Friedel 2007 (as in note 28), p. 17. 
resentation to colour, and the relation between figuration and abstraction. ${ }^{31}$ Richter's works like Rot - Gelb - Blau or Fiction, as well as his first Graue Bilder, were painted in the same period as the Annunciation after Titian. ${ }^{32}$ As has been repeatedly discussed, the long series of Grey pictures is a reflection on, but also an experience of crisis. ${ }^{33}$ What is at the heart of the matter is the question, or better still the paradox, already present in Caravaggio, of the representation of das Nichts. On December $27^{\text {th }}, 1985$ Richter reflected on the challenge, and maybe the impossibility of representing Nothing/ness. "Now", writes Richter, "since we very much want this visualization, but know it only as one that we can never have, it is an impossibility we experience, existentially, as an absolute limit. ${ }^{\prime \prime 4}$ Following this line of thought, Nothing/ness can certainly not be defined only in negative terms, as a lacuna, but rather as an integral part of creation: the desire to represent Nothing/ness goes along with a strategy for the persistence of artistic creation. These questions are also at the core of the Annunciation topic: how to represent the invisible in the visible, the non-figurable in the figurable. In this sense we believe Richter's intense engagement with Titian's Annunciation should not be reduced to a modernist act of (iconoclastic) deconstruction, but should rather be understood as the ideal matrix for

31 Gelshorn and Verhagen beautifully elucidate this aspect in their respective analyses of Richter's Annunciation. The focus on colorito, non-finito and blurriness is highly convincing from a purely art historical perspective, but does not take enough into consideration the deeper theological and also philosophical implications of the Annunciation-theme. Gelshorn 2012 (as in note 28), pp. 27-39.

32 For Rot - Gelb - Blau, see Friedel 2007 (as in note 28).

33 Elger convincingly argues that the Grey paintings are "at the same time a symptom of crisis and means to its defeat". Dietmar Elger, Gerhard Richter. Maler, Cologne: DuMont, 2002, p. 270. For a complex and brilliant analysis of Richter's constant use of grey see Benjamin H. D. Buchloh, Eight Gray. Between Vorschein und Glanz, in: Idem, Susan Cross (eds.), Gerhard Richter. Eight Gray, exh. cat. Berlin 2002-2003, New York, NY: Guggenheim Museum Publications, 2002, pp. 11-20.

34 The entire passage reads as follow: "Terrible and challenging, the blank canvas shows nothing - because the Something that is to take the place of Nothing cannot be evolved from Nothing, though the latter is so basic that one wants to believe in it as the necessary staring point. It is not possible to visualize Nothing. One way to gain some idea of that terrible state is through the impossibility of visualizing anything before, after or alongside the universe. Now, since we very much want this visualization, but know it only as one that we can never have, it is an impossibility that we experience, existentially, as an absolute limit. Thus, without a visualization, we stand in front of the empty canvas and can respond - as ever - only with ignorance and madness, by making what statement we can: a surrogate, basically, but one that we believe can somehow touch the impossible. (The advantage of my grey pictures is that they seem to unmask all other statements, whether object-bound or abstract, as surrogates, and arbitrary ones at that. In natural terms, however, they are still the same statements.) The abstract pictures are no less arbitrary than all object-bound representations (based on any old motif, which is supposed to turn into a picture). The only difference is that in these the 'motif' evolves only during the process of painting. So they imply that I do not know what I want to represent, or how to begin; that I have only highly imprecise and invariably false ideas of the motif that I am to make into a picture; and therefore that - motivated as I am solely by ignorance and frivolity - I am in a position to start." Richter 2009 (as in note 28), pp. 143-144 (Notes, 27 December 1985). 
further thinking and creating at the thresholds of (in)visibility. ${ }^{35}$ It is here where the attentive beholder can question the visual, and thus also epistemic certainties. ${ }^{36}$

And indeed, while the first of Richter's paintings readily allows for the Venetian master's iconography to be recognized, albeit still using his unmistakable technique of the Unschärfe, in the other canvas of the same dimension, with the same palette, mixing fresh paint with dry brushes, he produces a dissolution of the figures, with a disappearance and fusion of the angel in the Madonna that is pure abstraction and atmospheric effects (pl. III, fig. 6, 7). Richter returns to the Annunciation in three canvases of bigger dimensions in which the dissolution of perspective, colorito, impasto, pennellata, and light are thematized - aspects that are, so to speak, the essence of Titian's paintings, in which the relation between colour and incarnation are expressed both in an artistic and a theological sense. ${ }^{37}$ In Richter's blurriness, dissolutions and fusions, the familiar, seemingly well-known iconographical theme, becomes unfamiliar. It is only through the process of active looking that the beholder recognizes the theme again, and realizes how much light and colour are at the core of Titian's Annunciation in particular, and Annunciations in general. This dissolution of iconography also suggests a questioning of the theological implications of the Annunciation through the medium of painting, a medium that according to Richter can make the beholder experience transcendence. ${ }^{38}$ In the case of Richter, the question of how and what we see, and the idea of an active seeing that unveils the miraculous in the everyday (in what we thought was always known), is intrinsically connected to the artist's main task, that is making visible what is invisible and unmanageable, at the limits of Nothing - and this in turn is connected to belief. "The ability to believe", says Richter, "is our outstanding quality, and only art adequately translates it into reality. ${ }^{\prime 39}$ The artist's ethical responsibility, one could add, is to let art

35 Darryn Ansted, Post-Structuralism in the Artwork of Gerhard Richter, Ph. D. Thesis, The University of Western Australia, 2010, p.43. Ansted has an excellent point though, when he stresses that the original event - the Annunciation - might best be "represented by its own obscuring, and with a far more iconoclastic approach than representation." However, one should not forget that at the time Titian's free, dissolving use of colour was already extremely innovative. So the comparison of Renaissance-figuration-uncreative standardization versus Modernism-abstraction-creative deconstruction is not very fruitful. Instead, in his article The Annunciation of the Sensible, Wallenstein convincingly argues that Richter was aware of art theoretical discourse from the time of Titian and that in his painting the German artist tries to uncover possibilities within tradition itself. Wallenstein 2015 (as in note 28).

36 In his article Being in Uncertainties, Gavin Hopps uses Vattimo's concept of "pensiero debole", "weak thought", in discussing Richter's Annunciation after Titian. Hopps 2018 (as in note 28), p. 566.

37 Bohde 2002 (as in note 29).

38 "Art is not a substitute religion: it is a religion (in the true sense of the word: 'binding back', 'binding' to the unknowable, transcending reason, transcendent being)." Richter 2009 (as in note 28), p.34 (Notes, 1964-1965). Christian Lotz stresses that Richter evokes an idealist tradition, maybe without being aware of it. Christian Lotz, The Art of Gerhard Richter. Hermeneutics, Images, Meaning, London et. al.: Bloomsbury, 2015, p. 154.

39 Richter 2009 (as in note 28), p. 200 (Notes, 1988). 
come into being, into light, a feature that will also be of interest in the last part of this introduction.

\section{Silence \& Sound}

It is striking how the theme of announcing and annunciations is still present in contemporary installations and films. Beside the examples discussed in our volume, many others can be mentioned such as Pedro Almodóvar's Habla con Ella, in which there is an intricate net of references touching upon questions of announcing and voyeurism, or Andrei Tarkovsky's famous scene in Nostalghia, in which one of the main characters, Domenico, stands on the Campidoglio, denouncing Western civilization, its loss of moral coordinates, and implicitly announcing the end of the world, before burning himself with fuel. ${ }^{40}$ As in the case of Domenico, many announcements and prophecies are not necessarily heard; they disappear in the noise of a violent world - where Cassandra serves as the prototypical prophet in this vein, who is magisterially brought to life in Christa Wolf's $20^{\text {th }}$-century novel, Cassandra. In front of the Lion Gate of Mycenae, after having denied her last or lost love, and aware of her imminent death, the seeress proclaims: "It is not my voice that suffered, as they all thought. It is the tone. The tone of annunciation is gone"; and then she adds: "happily gone."41 In her novel Wolf consciously insists on the relation between content, form and expression of annunciations and revelations - here, the desire to find an appropriate language for announcing an undesired truth is intricately bound up with performative and etho-aesthetic issues. ${ }^{42}$

40 In the chapter "After Nostalgia" in Sculpting in Time, Tarkovsky writes that, even if Domenico might seem an irrelevant character at first sight, he is indeed of fundamental importance to the narrative. Domenico, who is portrayed as an outsider, is the one who has a clear understanding of responsibility and of the meaning of life: "This frightened, defenseless man finds in himself the strength and nobility of spirit to manifest his own understanding of the meaning of life. Once a mathematics teacher and now an 'outsider', undeterred by his lack of status, he decides to speak out about the catastrophic state of today's world. In the eyes of normal people he simply appears mad, but Gorchakov responds to his idea - born of deep suffering - of individual responsibility for all that is going on in the world, of each being guilty before everyone for everything." Andrei Tarkovsky, Sculpting in Time. The Great Russian Filmmaker Discusses his Art, trans. by Kitty Hunter-Blair, Austin: University of Texas Press, 1987, p. 205. For the transcription of the screen play into German and a commentary on the film, see Norbert P. Franz (ed.), Nostalghia. UdSSR/Italien, 1983. Regie: Andrej Tarkovskij Protokoll des Films, Übersetzung der Dialoge, Kommentar zum Film, Potsdam: Universitätsverlag Potsdam, 2015, pp.77-122.

41 Christa Wolf, Cassandra. A Novel and Four Essays, trans. by Jan van Heurck, New York, NY: Farrar, Strass and Giroux, 1984, p. 5.

42 Christa Wolf's Conditions of a Narrative. Cassandra (as in note 41), pp.141-305, originally delivered as a series of lectures on poetics at the University of Frankfurt in 1982, offer a deep insight into the poetic process and the main themes of her novel. The research literature on Wolf's Cassandra is far too exhaustive to mention here. For a good analysis of the novel see Nikolaos-Ioannis Koskinas, 'Fremd bin ich eingezogen, fremd ziehe ich wieder aus', von Kassandra, über Medea, zu Ariadne: Manifestationen der Psyche im spätesten Werk Christa Wolfs, Würzburg: Königshausen \& Neumann, 2008; Anna K. Kuhn, Christa Wolf's Utopian Vision. From Marxism to Feminism, Cambridge/New 
Silence and sound are also at the core of Tarkovsky's film Andrei Rublev (fig. 8-11). The film is dedicated to the life and work of the Russian Icon painter, who is famous for his works in the Muscovite Cathedral of the Annunciation and his Icon of the Trinity. ${ }^{43}$ In this film Tarkovsky raises several questions that are relevant to our topic, such as the integration of a personal story into the general history of a country and its people, the relation of art and reality, the necessity of dialogue, as well as theological and art-theoretical debates about truth and the ontological essence of art. ${ }^{44}$

It is especially the final of the eight "episodic novels" of the film, entitled The Bell which follows Silence - that is illuminating in our context. ${ }^{45}$ As it is well known, from Origen Adamantius onward, the bell was understood as the acoustic symbol of the announcement of the Christian message: its sound conjoins the divine and the human sphere and it structures the human time of believers. ${ }^{46}$ Bells play a fundamental role in Andrei Rublev. Early in the narration, Rublev quotes the famous passage from the First Epistle to the Corinthians, according to which, without Christian love, humans would be nothing more than "a sounding brass, or tinkling cymbal" (1 Corinthians 13:1). And it is ultimately through the crystalline sound of the bell, created by the young bell founder Boriska, that Rublev finds the way back to his own artistic voice. A voice he had deliberately abandoned after having killed a man. In the wake of this terrible event, Rublev

York: Cambridge University Press, 1988, esp. chapter 6, "Cassandra: Myth, Matriarchy, and the Canon", pp. 178-209.

43 For Andrei Rublev's Icon of the Trinity see for instance Anita Strezova, The Icon of the Trinity by Andrei Rublev, in: Eadem, Hesychasm and Art. The Appearance of New Iconographic Trends in Byzantine and Slavic Lands in the $14^{\text {th }}$ and $15^{\text {th }}$ Centuries, Canberra: ANU Press, 2014, pp. 173-232.

44 For Andrei Tarkovsky's film Andrei Rublev, see for instance Robert Bird, Andrei Rublev, London: British Film Institute, 2004; Natascha Drubek, Glocke und Ikone. Tarkovskijs Film 'Andrej Rublev', in: Norbert P. Franz (ed.), Andrej Tarkovskij-Klassiker, vol. 1, Potsdam: Universitätsverlag Potsdam, 2016, pp.153-192; Thomas Hensel, Regisseur als Autor als Maler. Zu Andrej Tarkowskijs Poetik einer Interikonizität, in: Idem, Klaus Krüger, Tanja Michalsky (eds.), Das Bewegte Bild. Film und Kunst, Munich: Fink, 2006, pp.217-256; Sean Martin, Andrei Tarkovsky, Harpenden: Pocket Essentials, 2005, esp. chapter 5, pp. 76-98; Nariman Skakov, The Cinema of Tarkovsky. Labyrinths of Space and Time, London/New York, NY: I. B. Tauris, 2012, esp. chapter 2, pp.42-73; Ekaterina Vassilieva, Schwarz-Weiß als Gestaltungsprinzip in 'Andrej Rublev' und 'Das Siebente Siegel', in: Norbert P. Franz (ed.), Andrej Tarkovskij-Klassiker, vol. 2, Potsdam: Universitätsverlag Potsdam, 2016, pp.451-470. For a philosophical analysis of Tarkovsky's oeuvre, see Marie-José Mondzain, Tarkovsky: Embodying the Screen, in: Roland Betancourt, Maria Taroutina (eds.), Byzantium/Modernism. The Byzantine as Method in Modernity, Leiden/Boston, MA: Brill, 2015, pp. 254-267. Tarkovsky theorises his film in Sculpting in Time. Tarkovsky 1987 (as in note 40), esp. chapters 2 and 3, pp. 36-81.

45 In her article, Drubek also insists on the importance of the bell and stresses the inextricable relation between sound and image. Drubek 2016 (as in note 44), esp. pp. 175-176. She writes: "Klang hier jedoch nicht im Sinne des gesprochenen Worts, sondern des Glockenlautens, dem in der russisch-orthodoxen Kultur eine besondere - auch nationale - Bedeutung zukommt. Ikone und Glocke (kolokol) greifen ineinander." However, she does not elaborate on the theological and philosophical implications of bell (as a symbol of the Announcement of the Christian message) and sound.

46 For a cultural history of the bell, see Kurt Kramer, Die Glocke. Eine Kulturgeschichte, Kevelaer: Topos, 2012, here pp. 20-23. 


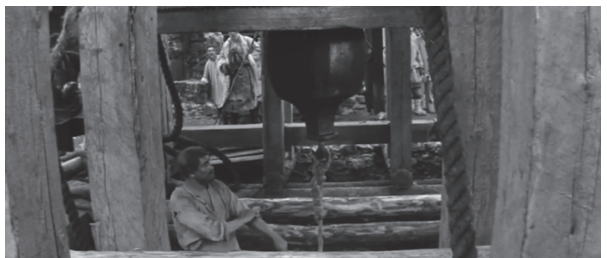

8 Andrei Tarkovsky, Andrei Rublev (film), 1966, Episode 8 - The Bell (still: 2.48.13)

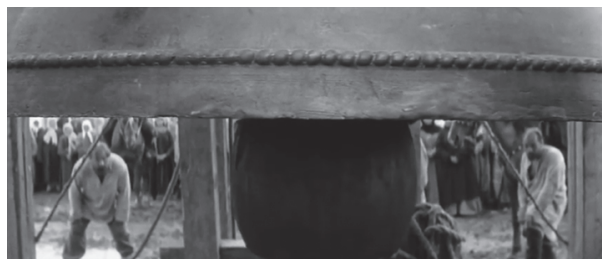

9 Andrei Tarkovsky, Andrei Rublev (film), 1966, Episode 8 - The Bell (still: 2.49.17)

starts to profoundly doubt not only himself, but also the necessity and sense of art "No one needs it" -, as well as the value of dialogue with other people - "I have nothing to tell people anymore." He thus makes a double vow of silence, one in speech, one in pictorial language, giving up painting as well. Only when Boriska succeeds in the bell-founding does Rublev finally break his vow and decides that he and Boriska will wander along and work together: "You will cast bells, I will paint icons. You made people very happy."

It is the double miracle of the creation of the bell and of its sound that dramatically changes the existence of Rublev. The first ringing of the bell, which has to be understood as an announcement that moves and resonates in the human being, possesses a highly symbolic quality: it is a rupture in time, connected to Andrei's awareness that nothing will be the same again. And indeed, the moment before the miracle will or will not occur - before the bell's clapper touches the lip of the bell, before sound comes into being is distinguished by an enormous narrative and visual tension, and a suspension of time (fig. 8, 9). ${ }^{47}$ In The Bell, which represents a film within the film, ${ }^{48}$ Tarkovsky also reflects on different epistemic forms: one based on clearly rational and scientific principles, the other deeply connected to faith and to a tacit, embodied knowledge. ${ }^{49}$ This opposition is beautifully epitomised in the figure of Boriska and the two Florentine ambassadors; they represent various degrees of epistemic expectation and readiness that condition the re-

47 Hensel rightly claims that in the film the ringing of bells always represents a turning point or a moment of recognition. Hensel 2006 (as in note 44), p. 230, footnote 57. However, he does not discuss the tight relationship between bells and Announcement.

48 Hensel 2006 (as in note 44), p. 227.

49 The difference between a human, organic, intuitive and a rationalist, even technological approach to existence and art is certainly one of the main motives in Tarkovsky's filmic oeuvre and in his theoretical reflections. In Sculpting in Time he writes: "And so art, like science, is a means of assimilating the world, an instrument for knowing it in the course of man's journey towards what is called 'absolute truth'. That, however, is the end of any similarity between these two embodiments of the creative human spirit, in which man does not merely discover, but creates. For the moment it is far more important to note the divergence, the difference in principle, between the two forms of knowing: scientific and aesthetic." Tarkovsky 1987 (as in note 40), p. 37. 
10 Andrei Tarkovsky, Andrei Rublev (film), 1966, Episode 8 - The Bell (still: 2.48.43)

11 Andrei Tarkovsky, Andrei Rublev (film), 1966, Episode 8 - The Bell (still: 2.51.47)
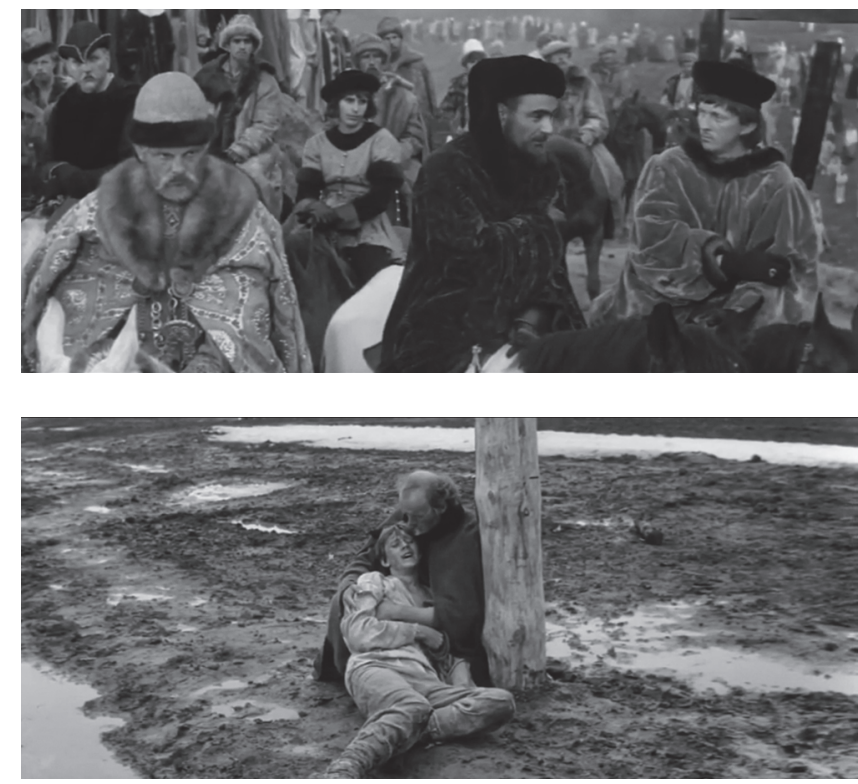

ception of the miracle and its subsequent comprehension. ${ }^{50}$ The Florentines and their entourage, who visually echo Benozzo Gozzoli's depiction of the Journey of the Magi in the Cappella dei Magi in Florence, disdain Boriska and the workers, and contest that the bell will ring. ${ }^{51}$ According to the ambassadors, the uncultivated Russians possess no true, scientific knowledge, and they sceptically observe the spectacle of the consecration of the bell (fig. 10). Nonetheless, captivated by the miracle of sound, they eventually change their mind and celebrate the bell's ringing. As Boriska confesses to the monk Andrei only at the end of the dramatic event, his father did not reveal him the secret of bell-founding before his death (fig. 11). Thus, Boriska could not follow a precise set of instructions based on traditional workshop practice - as annotated for instance in Ghiberti's Zibaldone $e^{52}$ - as he was trying to cast the object. Rather, he had to rely firstly on what he had seen and experienced by helping his father and uncle (both being famous bell founders themselves), and secondly on divine inspiration and grace. ${ }^{53}$

50 Cf. also Hensel 2006 (as in note 44), pp. 235-237. Hensel convincingly argues how in his film Tarkovsky was referring to and at the same time transforming the Italian pictorial tradition.

51 The contrast between Western and Eastern culture is an important trope in Andrei Rublev.

52 For Ghiberti's Zibaldone, cf. Giustina Scaglia, A Miscellany of Bronze Works and Texts in the 'Zibaldone' of Buonaccorso Ghiberti, in: Proceedings of the American Philosophical Society 120, 6 (1976), pp. 485-513.

53 Dubrek briefly refers to the loss of artisanal knowledge. However, she does not elaborate on the deeper epistemological implications of the topic. She writes: "(das) handwerkliche Geheimwissen des Glockengießens; es ging verloren aufgrund einer Epidemie und des Tatareneinfalls, den wir in 
The various levels of Tarkovsky's narrative are highly complex and polysemous, both from a philosophical and an artistic point of view; ${ }^{54}$ however, it becomes clear that what is at the centre of reflection is the question of silence and language - verbal as well as pictorial -, the relevance of interpersonal communication as the only possible means for human happiness, and the fundamental importance of the act of creation for humanity here exemplified by the act of creating a bell or painting Icons. In both cases, we witness a reversal of the process of announcement, inasmuch as the immaterial is created out of the material. The sound of the bell, to be understood as an analogon of word, is created out of matter, and the silent, visual language of painting makes visible the invisible through the materiality of colour. And it is certainly not by accident that in the epilogue, where Rublev's oeuvre is displayed in colour, Tarkovsky focuses on details and on the painterly, almost haptic surface of the Icons (thus emphasising their materiality). Significantly, in the epilogue, only one detail of the Annunciation, the model and matrix of all announcements, is shown: it is the descent of the Holy Spirit in the form of a dove. ${ }^{55}$ In the previous eight black-and-white episodes instead, the attentive beholder would have noticed quite mundane white birds fluttering into the visual and imaginative space of the movie, playfully reenacting and variating the original (static) motif. Of course, when Tarkovsky writes that "through the image is sustained an awareness of the infinite" he does by no means refer to images of the Annunciation stricto sensu. ${ }^{56}$ For him it is the moving image as such that constitutes a privileged site for the entry of the divine into the human sphere. This is why Tarkovsky's theorizing about the possibilities and limits of representing the irrepresentable in art is a challenging appropriation and transformation of many questions intrinsic to our matter. Nowadays, however, art doesn't necessarily have to be "a detector of the absolute". ${ }^{57}$ Rather, it can be a medium that raises our awareness of the invisible that is always part of the visible, immanent world - the greatest miracle could be to reveal the visible that we are no longer able to perceive. And perhaps today's announcements are prophecies of an unknown everyday.

der vorangehenden Novelle gesehen haben. Außer Boriska sind alle im Dorf der Glockengießer gestorben. Boriska erwähnt später voller Wut, dass sein Vater ihm das Geheimnis nicht verraten hätte - was auf eine orale und nichtschriftliche Überlieferung dieses Wissens hindeutet, die zudem eine missglückte Vater-Sohn-Linie darstellt, die Rublev heilen kann." Dubrek 2016 (as in note 44), p. 184 .

54 Mondzain 2015 (as in note 44).

55 Cf. Bird 2004 (as in note 44), p.73.

56 In Sculpting in Time Tarkovsky writes in a quite idealistic impetus: "Artistic discovery occurs each time as a new and unique image of the world, a hieroglyphic of absolute truth. It appears as a revelation, as a momentary, passionate wish to grasp intuitively and at a stroke all the laws of this world - its beauty and ugliness, its compassion and cruelty, its infinity and its limitations. The artist expresses these things by creating the image, sui generis detector of the absolute. Through the image is sustained an awareness of the infinite: the eternal within the finite, the spiritual within matter, the limitless given form." Tarkovsky 1987 (as in note 40), p. 37.

57 Ibid. 